\title{
PEMBUATAN PROGRAM APLIKASI KONSTRUKSI DINDING PENAHAN TANAH UNTUK KONDISI GEMPA DENGAN VISUAL BASIC 6.0
}

\author{
Rina Yuliet ${ }^{1}$, Abdul Hakam ${ }^{2}$, Isyendo Firtsilova ${ }^{3}$ dan Faharisatel Anafwil ${ }^{4}$
}

\begin{abstract}
ABSTRAK
Dinding Penahan Tanah (Retaining Wall) merupakan salah satu konstruksi yang digunakan untuk menahan tanah atau memberikan kestabilan kepada tanah yang memiliki beda ketinggian, sehingga tidak mengalami kelongsoran. Sampai saat ini metoda yang sering digunakan untuk menghitung struktur ini adalah metoda coba-coba, dengan metoda ini akan dibutuhkan waktu yang lama, terutama bagi mereka yang belum berpengalaman. Oleh karena itu sangatlah perlu untuk dikembangkan suatu program komputer yang dapat membantu proses perhitungan struktur ini. Dengan harapan waktu dan tenaga yang dibutuhkan lebih efisien (karena segala perhitungan akan dilakukan oleh komputer) dan tentu saja akan menghasilkan tingkat akurasi dan ketelitian yang lebih tinggi dibandingkan dengan perhitungan secara manual dengan metoda coba-coba. Tujuan dari penelitian ini adalah membuat program bantu untuk menghitung stabilitas konstruksi dinding penahan tanah pada kondisi gempa dengan menggunakan progran Visual Basic 6.0. Dari hasil analisis dengan menggunakan program dinding penahan tanah ini didapatkan dimensi dinding penahan tanah yang aman, relatif ekonomis sesuai dengan keperluan secara tepat dan mudah, hasil perhitungan dengan tingkat ketelitian yang lebih akurat dibandingkan dengan perhitungan secara coba-coba, dan juga waktu dan tenaga yang dibutuhkan juga lebih efisien.
\end{abstract}

Kata kunci : dinding penahan tanah, kondisi statis, kondisi gempa, visual basic 6

\section{PENDAHULUAN}

Konstruksi dinding penahan tanah sering digunakan untuk menahan atau menopang suatu peninggian tanah, onggokan batu bara, onggokan biji tambang ataupun air. Supaya dapat menahan tanah yang memiliki kondisi khusus tersebut, konstruksi ini harus mampu memberikan kestabilan terhadap pengaruh gaya-gaya eksternal seperti tekanan tanah yang berada dibelakang dinding dan gaya gempa yang dapat menyebabkan keruntuhan guling, keruntuhan geser dan keruntuhan daya dukung tanah. Sampai saat ini metode yang sering digunakan untuk menghitung struktur ini adalah metode coba-coba.

Tim Peneliti dan Pengembangan Wahana Komputer tahun 2002 membuat suatu program aplikasi dinding penahan tanah (Retaining Wall) dengan Visual Basic 6.0. Program yang dibuat oleh tim tersebut mendorong kami untuk membuat program yang lebih baik lagi dimana pada program yang akan dibuat mempertimbangkan struktur dinding penahan tanah yang aman terhadap beban gempa.

\footnotetext{
${ }^{1}$ Staf Pengajar Jurusan Teknik Sipil Fakultas Teknik Universitas Andalas, rina@ft.unand.ac.id

${ }^{2}$ Staf Pengajar Jurusan Teknik Sipil Fakultas Teknik Universitas Andalas, abdulhakam@ft.unand.ac.id

${ }^{3}$ Mahasiswa Jurusan Teknik Sipil Fakultas Teknik Universitas Andalas

${ }^{4}$ Mahasiswa Jurusan Teknik Sipil Fakultas Teknik Universitas Andalas
} 
Berikut ini adalah perbedaan penelitian yang dilakukan oleh Tim Peneliti dan Pengembangan Wahana Komputer dengan penelitian yang akan kami lakukan.

Tabel 2.1. Dasar teori, batasan masalah, keluaran

\begin{tabular}{|c|c|c|c|}
\hline & $\begin{array}{l}\text { Teori yang } \\
\text { digunakan }\end{array}$ & Batasan masalah & Keluaran \\
\hline $\begin{array}{l}\text { Tim peneliti } \\
\text { Wahana } \\
\text { Komputer, } \\
2002\end{array}$ & $\begin{array}{l}\text { Menggunakan teori } \\
\text { Rankin }\end{array}$ & $\begin{array}{l}\text { a. Tidak memperhitungkan adanya } \\
\text { muka air tanah di kiri dan kanan } \\
\text { dinding penahan tanah } \\
\text { b. Tidak mempertimbangkan beban } \\
\text { gempa }\end{array}$ & $\begin{array}{l}\text { Stabilitas guling, geser } \\
\text { dan daya dukung tanpa } \\
\text { pengaruh beban gempa }\end{array}$ \\
\hline $\begin{array}{l}\text { Penelitian } \\
\text { yang akan } \\
\text { dilakukan }\end{array}$ & $\begin{array}{l}\text { Menggunakan teori } \\
\text { Coulomb dan } \\
\text { Persamaan } \\
\text { Mononabe - Okabe }\end{array}$ & $\begin{array}{l}\text { a. Ada muka air di kiri dan kanan } \\
\text { dinding penahan tanah (Gambar } \\
\text { 2.1) } \\
\text { b. Mempertimbangkan beban } \\
\text { gempa }\end{array}$ & $\begin{array}{l}\text { Stabilitas guling, geser } \\
\text { dan daya dukung } \\
\text { dengan pengaruh beban } \\
\text { gempa }\end{array}$ \\
\hline
\end{tabular}

Program ini khusus untuk dinding penahan tanah jenis dinding gravity akibat beban gempa dengan bentuk seperti pada Gambar 2.1 :

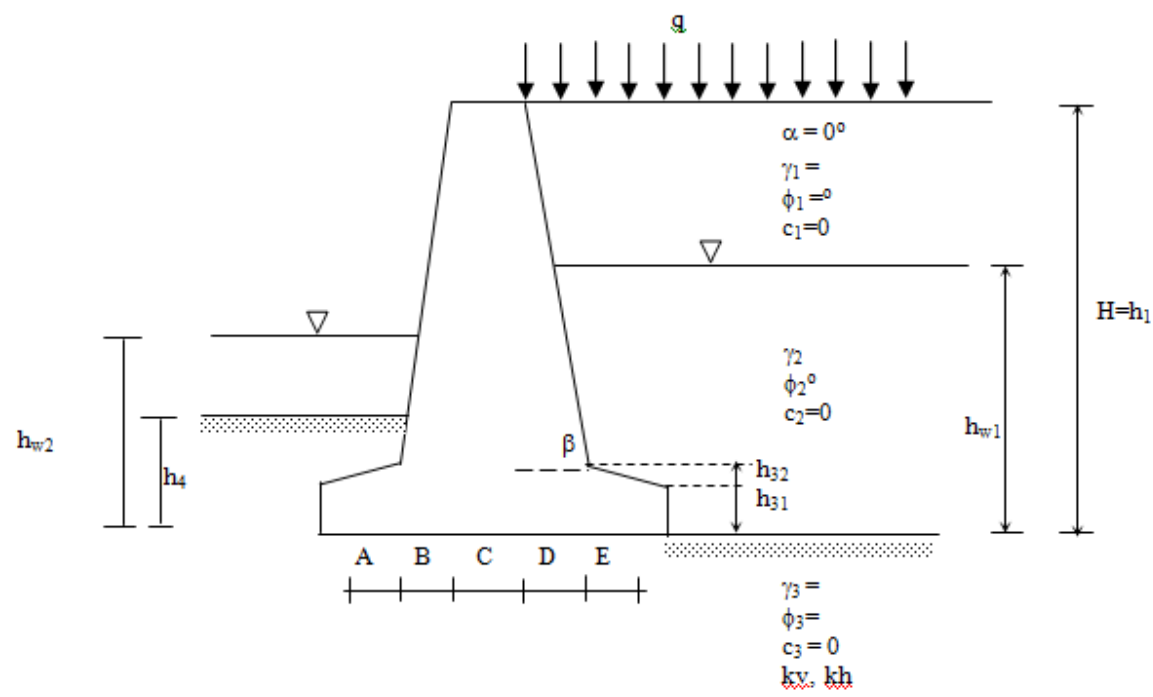

Gambar 2.1. Dinding penahan tanah akibat beban gempa dengan muka air tanah

Dalam merencanakan dinding penahan tanah maka yang harus dilakukan adalah :

a. Mengasumsikan suatu dimensi

b. Lakukan check stabilitas (guling, geser dan daya dukung) terhadap dimensi yang direncanakan.

c. Jika dari hasil check stabilitas tidak dipenuhi, maka dimensi penampang dapat dirobah lagi dan dicek lagi terhadap stabilitas.

\subsection{Tekanan Tanah Aktif akibat Beban Statis (Coulomb)}

Gaya tekan aktif Coulomb akibat beban statis adalah :

$$
P_{a}=\frac{1}{2} \gamma H^{2} K_{a}
$$

Dimana :

$$
\mathrm{K}_{\mathrm{a}}=\frac{\sin ^{2}(\beta+\phi)}{\sin ^{2} \beta \sin (\beta-\delta)\left[1+\sqrt{\frac{\sin (\phi+\delta) \sin (\phi-\alpha)}{\sin (\beta-\delta) \sin (\alpha+\beta)}}\right]^{2}}
$$




\subsection{Tekanan Tanah Aktif Akibat Beban Gempa (Mononobe-Okabe)}

Gaya aktif persatuan panjang dinding akibat gempa (persamaan Mononabe-Okabe) adalah sebagai berikut :

$$
\begin{aligned}
& \mathrm{P}_{\mathrm{ae}}= \frac{1}{2} \gamma \mathrm{H}^{2}\left(1-\mathrm{k}_{\mathrm{v}}\right) \mathrm{K}_{\mathrm{ae}} \\
& \mathrm{K}_{\mathrm{ae}}=\frac{\sin ^{2}\left(\phi+\beta-\theta^{\prime}\right)}{\cos \theta^{\prime} \sin ^{2} \beta \sin \left(\beta-\theta^{\prime}-\delta\right)\left[1+\sqrt{\frac{\sin (\phi+\delta) \sin \left(\phi-\theta^{\prime}-\alpha\right)}{\sin \left(\beta-\delta-\theta^{\prime}\right) \sin (\alpha+\beta)}}\right]^{2}}
\end{aligned}
$$

Untuk menentukan lokasi resultan gaya dari tekanan tanah aktif akibat beban gempa $\left(\mathrm{P}_{\mathrm{ae}}\right)$ maka harus dilakukan langkah sbb :

a. Hitung $\Delta \mathrm{P}_{\mathrm{ae}}$

$$
\Delta \mathrm{P}_{\mathrm{ae}}=\mathrm{P}_{\mathrm{ae}}-\mathrm{P}_{\mathrm{a}}
$$

b. Asumsikan bahwa $\Delta \mathrm{P}_{\mathrm{ae}}$ berada pada jarak $0,6 \mathrm{H}$ dari dasar dinding (Gambar 2.2)

c. Hitunglah lokasi resultan gaya $\left(\mathrm{P}_{\mathrm{ae}}\right)$ :

$$
Z^{\prime}=\frac{0,6 \mathrm{H}\left(\Delta \mathrm{P}_{\mathrm{ae}}\right)+(\mathrm{z})\left(\mathrm{P}_{\mathrm{a}}\right)}{\mathrm{P}_{\mathrm{ae}}}
$$

\subsection{Tekanan Tanah Pasif akibat Beban Statis (Coulomb)}

Tekan tanah pasif Coulomb akibat beban statis adalah :

$$
P_{a}=\frac{1}{2} \gamma H^{2} K_{a}
$$

Dimana :

$$
K_{p}=\frac{\sin ^{2}(\beta-\phi)}{\sin ^{2} \beta \sin (\beta+\delta)\left[1-\sqrt{\frac{\sin (\phi+\delta) \sin (\phi+\alpha)}{\sin (\beta+\delta) \sin (\alpha+\beta)}}\right]^{2}}
$$

\subsection{Tekanan Tanah Pasif akibat Beban Dinamis (Mononabe-Okabe)}

Tekanan tanah pasif akibat beban dinamis dapat dihitung dengan menggunakan persamaan Mononabe-Okabe sbb :

$$
\mathrm{P}_{\mathrm{Pe}}=\frac{1}{2} \gamma \mathrm{H}^{2}\left(1-\mathrm{K}_{\mathrm{v}}\right) \mathrm{K}_{\mathrm{Pe}}
$$

dimana :

$$
\mathrm{K}_{\mathrm{pe}}=\frac{\sin ^{2}\left(\beta+\theta^{\prime}-\phi\right)}{\cos \theta^{\prime} \sin ^{2} \beta \sin \left(\delta+\beta+\theta^{\prime}-90\right)\left[1-\sqrt{\frac{\sin (\phi+\delta) \sin \left(\phi_{3}-\theta^{\prime}+\alpha\right)}{\sin \left(\beta+\delta+\theta^{\prime}\right) \sin (\alpha+\beta)}}\right]^{2}}
$$

\subsection{Stabilitas Dinding Penahan Tanah}

Untuk menghitung stabilitas dinding penahan tanah maka perlu diuraikan komponen gaya-gaya yang bekerja di sebelah kiri dan kanan dinding. Uraian dari komponen gaya-gaya yang bekerja dapat dilihat pada Gambar 2.2. 


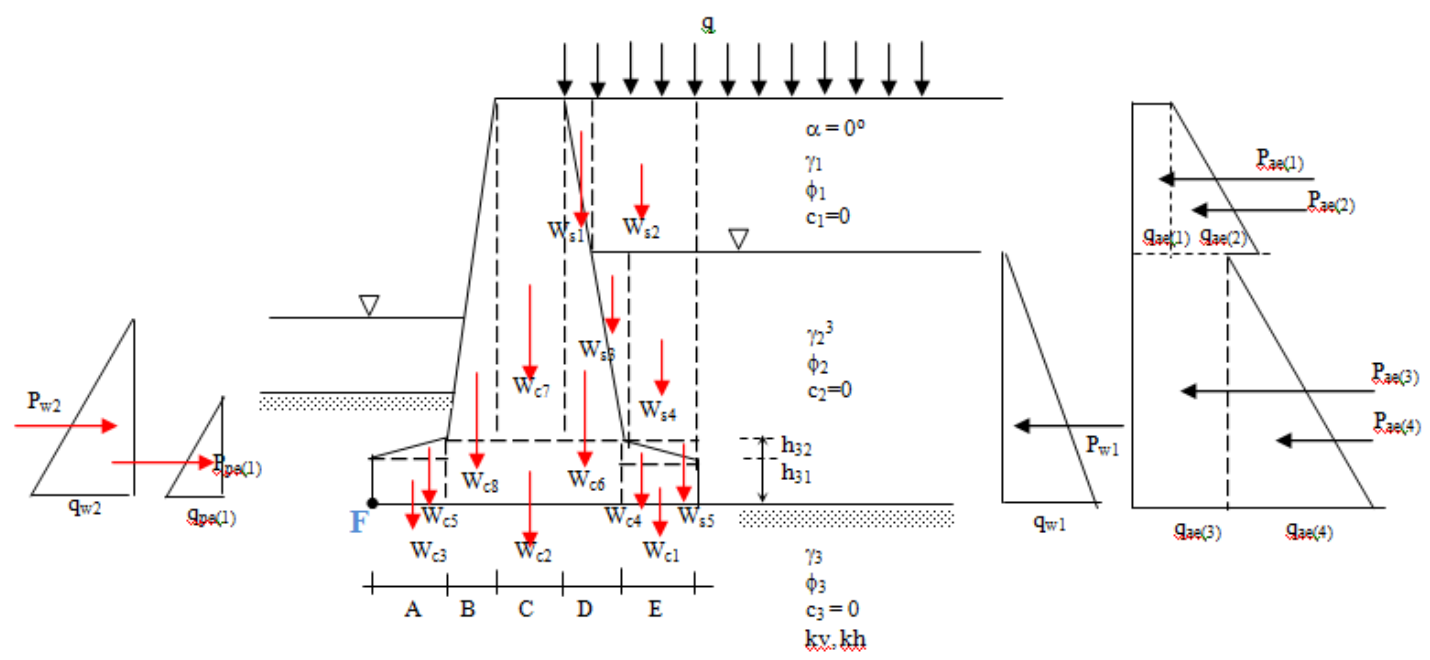

Gambar 2.2. Komponen Gaya-Gaya yang Bekerja Pada Dinding Penahan Tanah

\subsubsection{Stabilitas Dinding akibat Beban Statis}

a. Faktor Keamanan terhadap Guling pada Titik F

$$
\mathrm{FS}_{\text {(guling) }}=\frac{\sum \mathrm{M}_{\mathrm{R}}}{\sum \mathrm{M}_{\mathrm{O}}}
$$

b. Faktor Keamanan terhadap Geser

$$
\mathrm{FS}_{\text {(geser) }}=\frac{\mathrm{C}_{3} L+\sum V \tan \phi_{3}+\mathrm{P}_{\mathrm{p}(1)}+\mathrm{P}_{\mathrm{w} 2}}{\mathrm{P}_{\mathrm{a}(\text { total })}}>1,5
$$

c. Faktor Keamanan terhadap Keruntuhan Daya Dukung

Menentukan nilai eksentrisitas (e) sbb :

$$
e=\frac{L}{2}-\frac{\sum M_{R}-\sum M_{O}}{\sum V}<\frac{L}{6}
$$

Menentukan $\mathrm{q}_{\text {toe }}$ dan $\mathrm{q}_{\text {heel }}$ :

$$
\begin{aligned}
& \mathrm{q}_{\max }=\frac{\sum \mathrm{V}}{\mathrm{B}}\left(1+\frac{6 \mathrm{e}}{\mathrm{L}}\right) \\
& \mathrm{q}_{\min }=\frac{\sum \mathrm{V}}{\mathrm{B}}\left(1-\frac{6 \mathrm{e}}{\mathrm{L}}\right)
\end{aligned}
$$

Menentukan daya dukung batas (ultimate) dari tanah :

$$
\mathrm{q}_{\mathrm{u}}=\mathrm{c}_{3} \mathrm{~N}_{\mathrm{c}}+\mathrm{qN} \mathrm{N}_{\mathrm{q}}+\frac{1}{2} \gamma_{3} \mathrm{~L}^{\prime} \mathrm{N}_{\gamma}
$$

Faktor keamanan terhadap keruntuhan daya dukung adalah :

$$
\mathrm{FS}_{\text {(daya dukung) }}=\frac{\mathrm{q}_{\mathrm{u}}}{\mathrm{q}_{\max }}>3
$$

\subsubsection{Stabilitas Dinding akibat Beban Dinamis}

Stabilitas terhadap guling dan keruntuhan daya dukung dapat digunakan persamaan (11) dan persamaan (17). Untuk stabilitas terhadap geser digunakan persamaan sbb :

$$
\mathrm{FS}_{\text {(geser) }}=\frac{\mathrm{C}_{3} \mathrm{~L}+\sum \mathrm{V} \tan \phi_{3}+\mathrm{P}_{\mathrm{pe}(1)}+\mathrm{P}_{\mathrm{w} 2}}{\mathrm{P}_{\text {ae(total) }}}>1.5
$$

\section{METODE PENELITIAN}


Pengaturan pola pikir jalannya program ini tidak sulit, cukup dengan mencoba memikirkan langkah-langkah yang akan ditempuh bila menghitung secara manual. Kemudian langkah-langkah tersebut diimplementasikan dalam satu pola pikir pembuatan program. Setelah semakin jelas pola pikir untuk pembuatan program, maka mulailah melakukan langkah-langkah untuk mewujudkan atau mengimplementasikan perencanaan melalui diagram alir (Flow chart). Karena dengan membuat diagram alir berarti telah merumuskan pola pikir dalam membuat program kedalam suatu diagram sehingga memudahkan untuk meneliti kekurangan dari program yang akan dibuat untuk dicari pemecahannya. Bila tidak bisa, alternative lain adalah masalah tersebut dijadikan batasan perencanaan sehingga tidak akan mengganggu jalannya program.

\subsection{Konsep Perancangan Program}

Perancangan program aplikasi konstruksi dinding penahan tanah ini sangatlah penting dilakukan karena pada program kita dapat menginputkan data-data dan juga dapat melihat hasil dari data yang diinputkan tersebut. Dalam perancangan program kita harus mempertimbangkan bentuk dari program yang kita buat dan juga kemudahan dalam penggunaanya, sehingga pemakai nantinya dapat menjalankan program dengan baik.

\subsection{Disain Form-form}

Form adalah sebuah objek yang digunakan sebagai tempat untuk meletakkan objek-objek lain diatasnya. Untuk membuat suatu program kita harus mendisain form-form sedemikian rupa sehingga program kita dapat berfungsi sebagaimana mestinya. Adapun jenis form yang digunakan dalam program konstruksi dinding penahan tanah ini adalah:
a. Form induk (MDI Form)
b. Form Anak (MDI Child)
c. Splash Form
d. About Dialog

\subsection{Tipe Variabel Data}

Tipe data diperlukan untuk dapat mengatur bentuk dari input atau output data yang kita gunakan. Tipe data yang digunakan dalam pembuatan program analisis dinding penahan tanah ini adalah tipe data single.

a. Penggunaan memori dan rentang data

Ada perbedaan pengalokasian untuk satu tipe data dengan tipe data yang lainnya. Menggunakan tipe data yang penggunaanya memori paling kecil adalah cara yang paling baik.Misalnya jika anda ingin memproses data nilai yang mempunyai Range (rentang) 0 sampai 100 tanpa desimal maka yang paling tepat data Byte (pelu memori 1 byte),dibandingkan bila anda menggunakan tipe Integer atau Long.

b. Ketelitian Perhitungan

Ketelitian perhitungan sangat diperlukan sehingga diperlukan meggunakan tipe data dengan ketelitian (presisi) paling tinggi,tipe data single mempunyai ketelitian 6 digit dibelakang titik desimal, sedangkan double mempunyai ketelitian 14 digit dibelakang titik desimal. Tapi dalam program ini format output ditampilkan 2 digit dibelakang koma.

\section{HASIL DAN PEMBAHASAN}

Analisa yang dilakukan terhadap program yang dibangun dilakukan dengan 2 cara, yaitu verifikasi dan validasi. Proses verifikasi dan validasi harus ada di setiap tahap proses perangkat lunak. Adapun tujuan utama dari verifikasi dan validasi adalah untuk menemukan cacat atau kesalahan 
yang terdapat pada perangkat lunak yang dibangun dan untuk menilai apakah perangkat lunak telah di bangun sesuai dengan spesifikasinya.

\subsection{Verifikasi}

Proses verifikasi dilakukan untuk mengetahui apakah perangkat lunak yang dibangun telah berjalan dengan benar dan sesuai dengan spesifikasi yang ada. Proses verifikasi sendiri terbagi atas 2 cara yaitu dengan cara pengecekkan dan pengujian perangkat lunak yang dibangun. Pengecekkan perangkat lunak yang dibangun meliputi form-form dan kode-kode program yang telah di disain. Pengecekkan ini bertujuan untuk menemukan kesalahan-kesalahan seperti : kesalahan pada rumus yang digunakan, kode program, dll. Pengujian perangkat lunak yang telah dibangun bertujuan untuk menemukan kesalahan-kesalahan (error) yang lebih khusus seperti kesalahan pada hubungan antara 1 form dengan form lainnya. Berikut ini adalah hasil pembuatan program aplikasi dinding penahan tanah dengan form-form sebagai berikut :

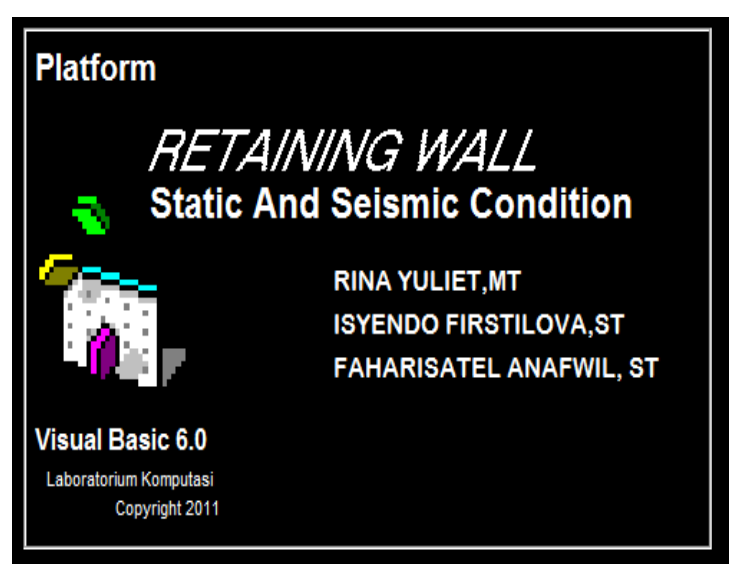

Gambar 3.1. Splash Form

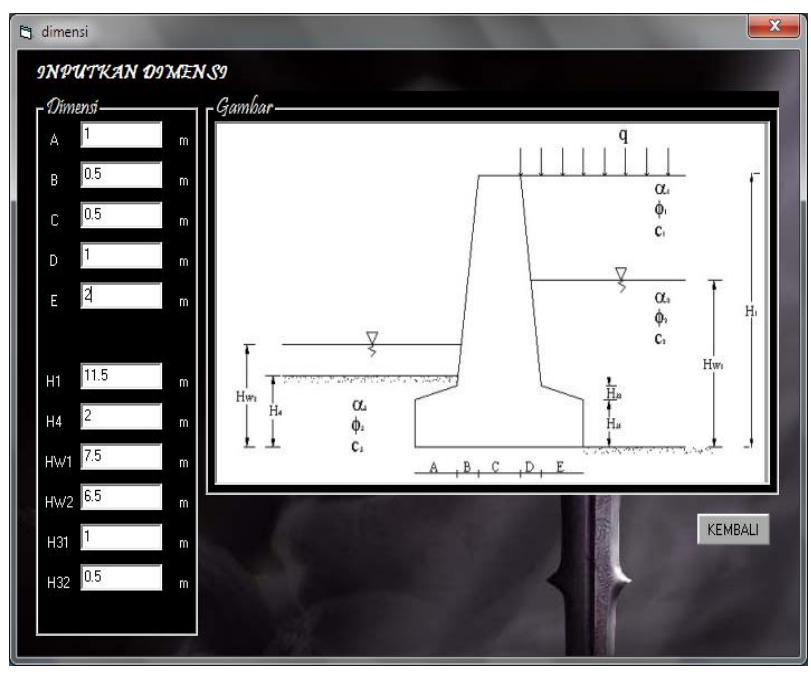

Gambar 3.3. Tampilan Input Data Dimensi Awal

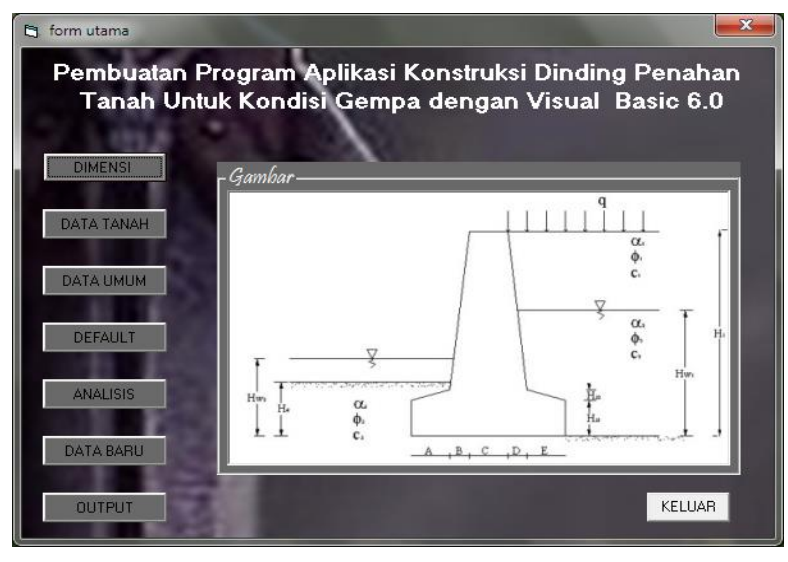

Gambar 3.2. Form Utama

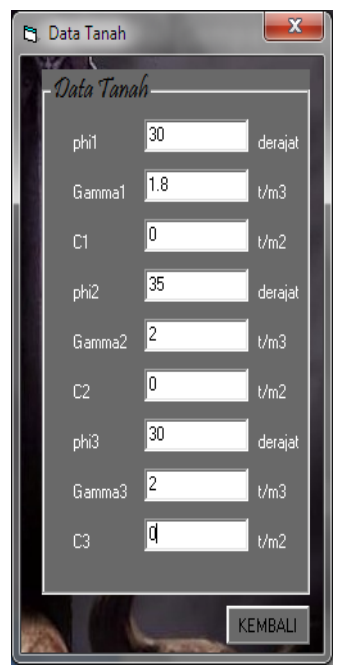

Gambar 3.4.

Tampilan Input Data Tanah

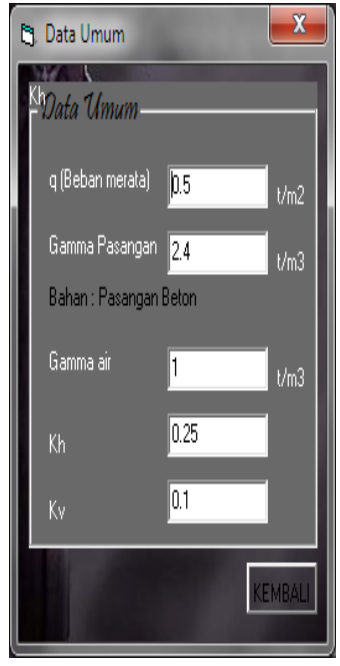

Gambar 3.5. Tampilan Input Data Umum 


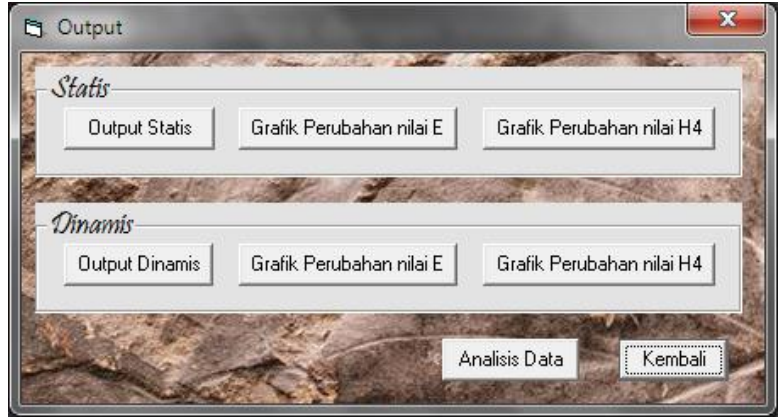

Gambar 3.6. Form output

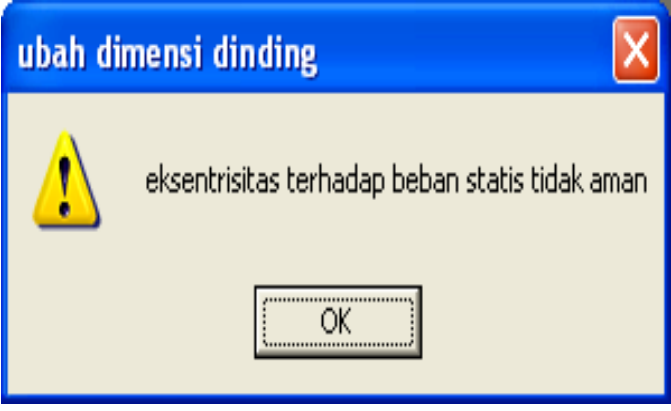

Gambar 3.7. Tanda Peringatan terhadap Beban Statis

Setelah program di running diperoleh hasil seperti gambar 3.7. Dari gambar 3.7 tersebut kita diminta untuk mengubah dimensi dari dinding, karena nilai eksentrisitasnya (1.19) besar dari B/6 (0.83) (Gambar 3.8), yang menyebabkan $\mathrm{q}_{\min }$ menjadi negatif. Ini menunjukan bahwa akan terjadi beberapa tegangan tarik pada ujung penampang heel. Tegangan ini tidak layak karena kekuatan tarik dari tanah sangat kecil. Berdasarkan hal tersebut maka dimensi dinding harus dirubah pada bagian tertentu dan perhitungan dilakukan kembali.

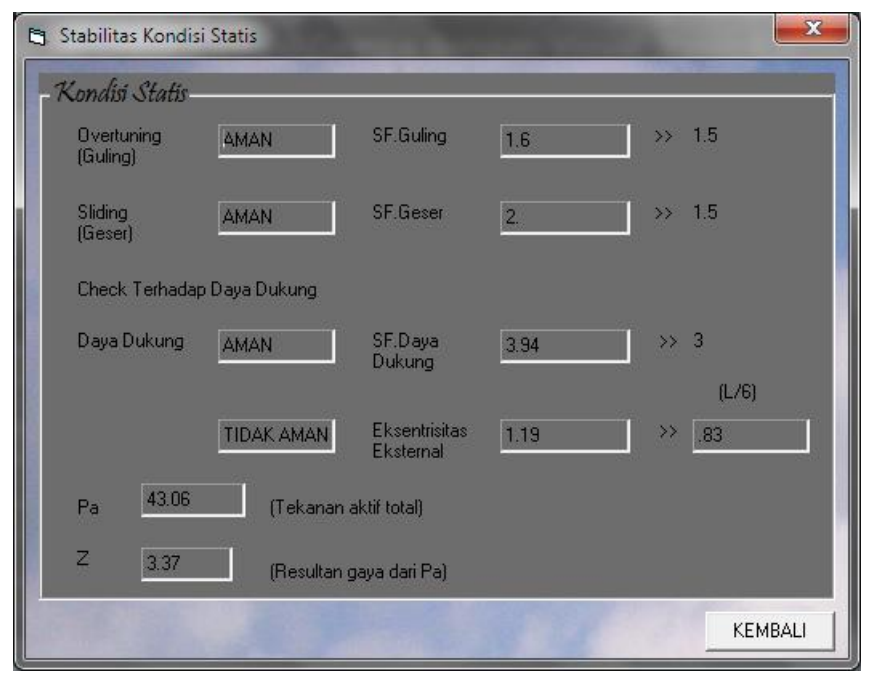

Gambar 3.8. Hasil Analisis terhadap Beban Statis

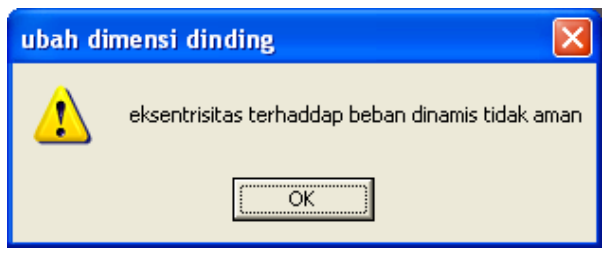

Gambar 3.9. Tanda Peringatan terhadap Beban Dinamis

Untuk kondisi dinamis terjadi hal yang sama setelah program di running atau dianalisis ,dimana dari Gambar 3.9 tersebut kita juga diminta untuk mengubah dimensi dari dinding, karena nilai eksentrisitasnya (2.31) besar dari B/6 (0.83) (Gambar 3.10), ini berarti dimensi dinding harus dirubah pada bagian tertentu dan perhitungan dilakukan kembali.

Untuk mendapatkan nilai eksentrisitas yang lebih kecil dari B/6 maka salah satu cara adalah dengan menambah panjang dasar slab pada bagian heel dan memperbesar tekanan tanah pasif. Setelah dilakukan perubahan dimensi pada bagian heel (Gambar 3.11) maka diperoleh hasil seperti pada Gambar 3.12 dan 3.13, dimana untuk kondisi statis nilai eksentrisitas sudah menunjukan nilai yang lebih kecil dari B/6 (dimana $0.29<1.75$ ). Begitu juga pada kondisi dinamis dimana nilai eksentrisitasnya juga kecil dari B/6 $(0.78<1.75)$. Setelah mendapatkan dimensi yang benar-benar ekonomis dan aman maka proses dihentikan. 


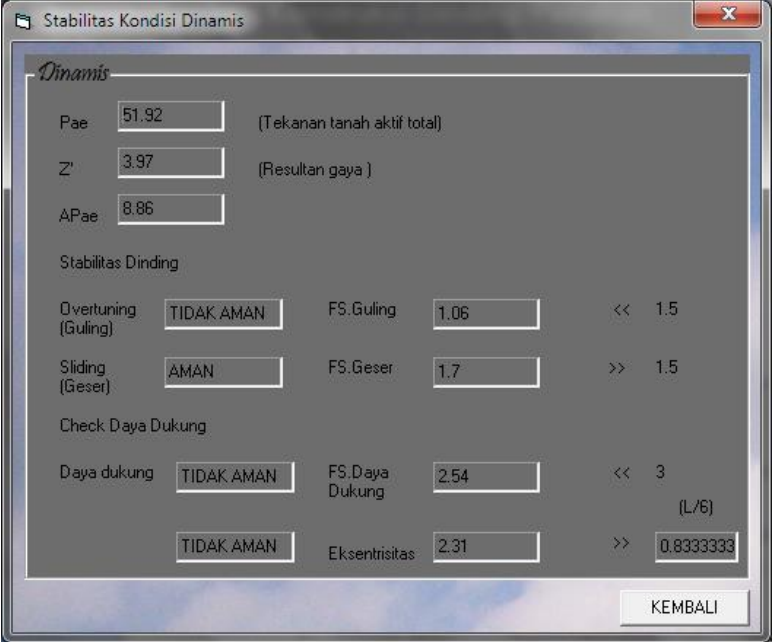

Gambar 3.10. Hasil Analisis terhadap Beban Dinamis

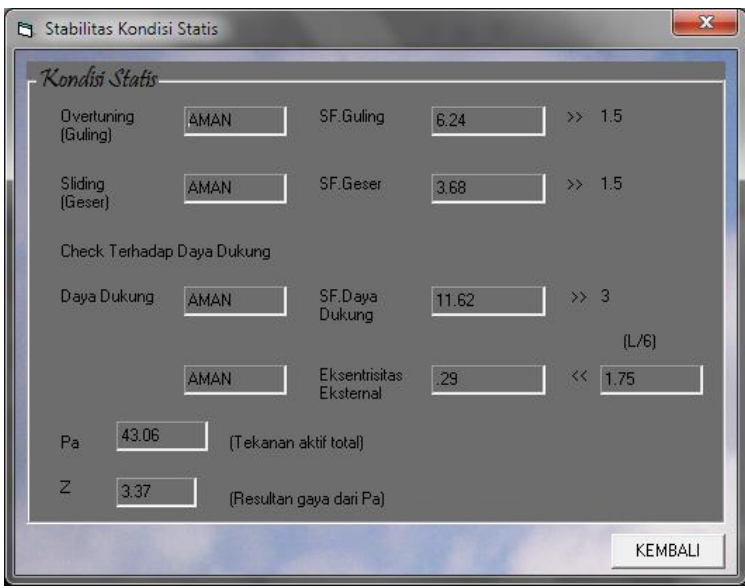

Gambar 3.12 Hasil Analisis Data Baru terhadap Beban Statis

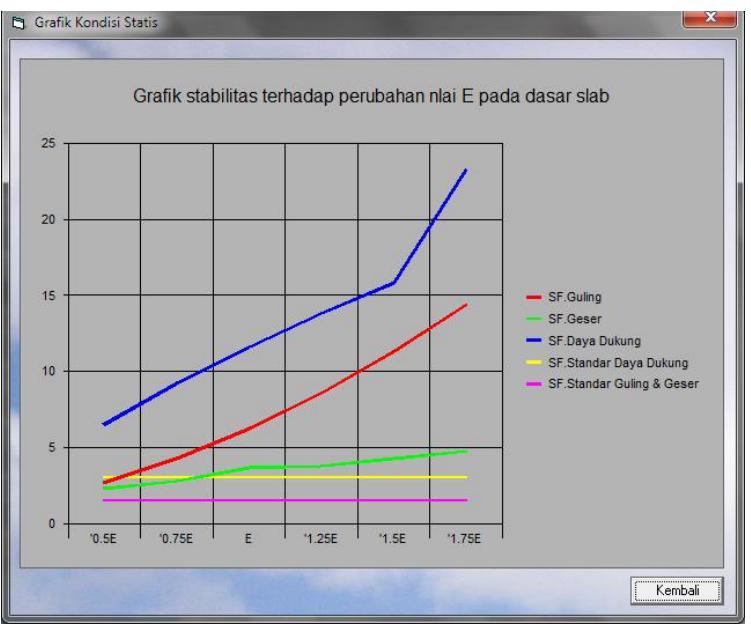

Gambar 3.14. Grafik Perubahan Nilai Stabilitas Berdasar Nilai E Pada Kondisi Statis

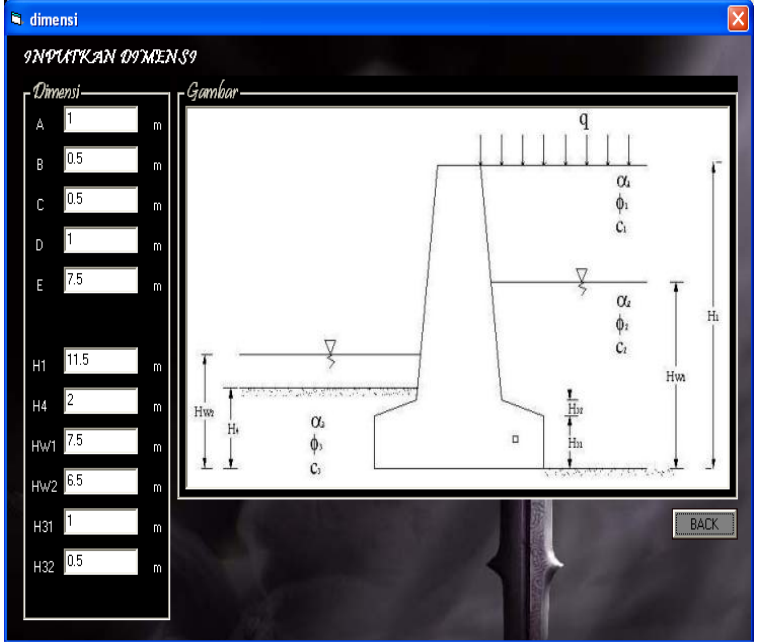

Gambar 3.11. Input Data Dimensi Baru

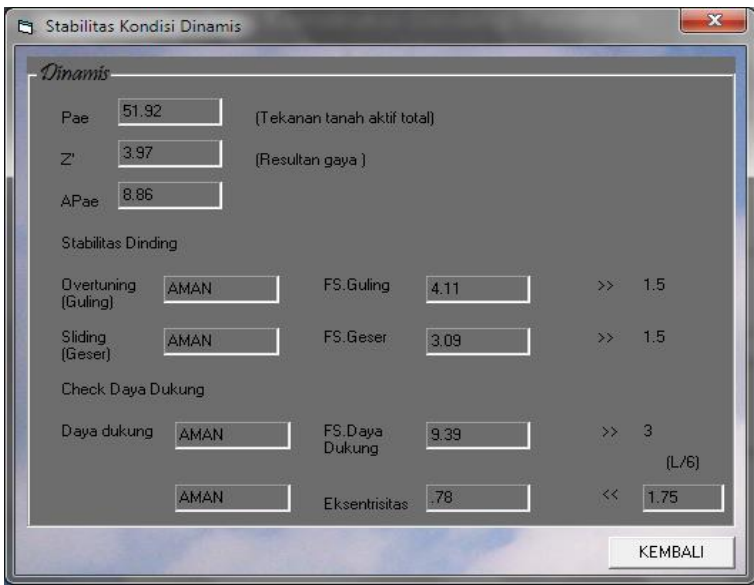

Gambar 3.13. Hasil Analisis Data Baru terhadap Beban Dinamis

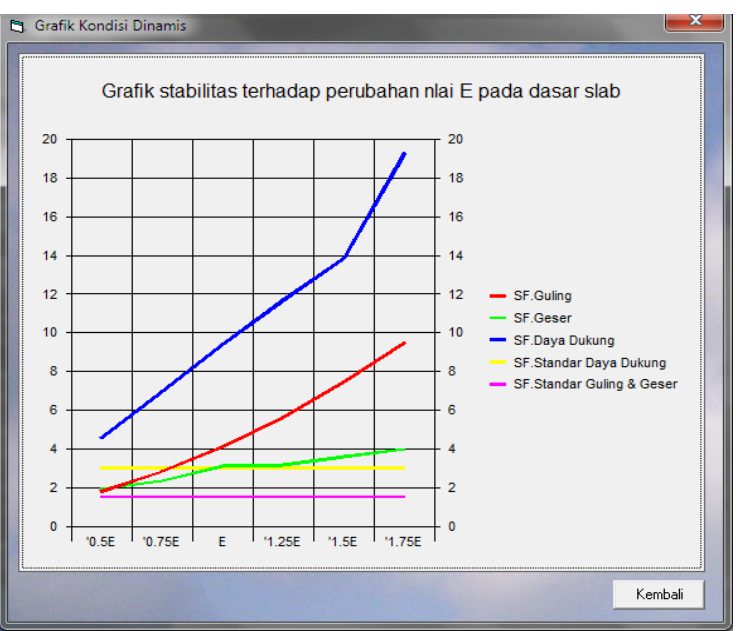

Gambar 3.15. Grafik Perubahan Nilai Stabilitas Berdasar Nilai E Pada Kondisi Dinamis 
Gambar 3.14 dan Gambar 3.15 menunjukan hubungan antara dimensi $E$ dengan faktor keamanan terhadap guling, geser dan daya dukung pada kondisi statis dan dinamis. Grafik ini dapat digunakan sebagai acuan untuk melihat stabilitas dinding penahan tanah dengan cara merubah dimensi pada bagian heel (memperkecil atau memperbesar dimensi pada bagian E), sehingga didapatkan dimensi dinding penahan tanah yang lebih efisien dan aman.

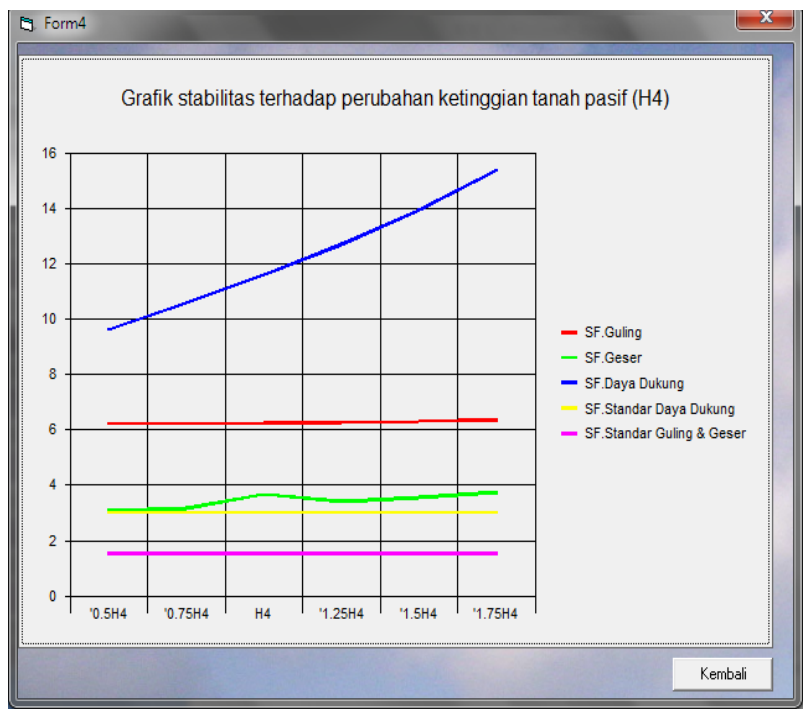

Gambar 3.16. Grafik Perubahan Nilai Stabilitas Dinding berdasar Nilai $\mathrm{H}_{4}$ pada Kondisi Statis

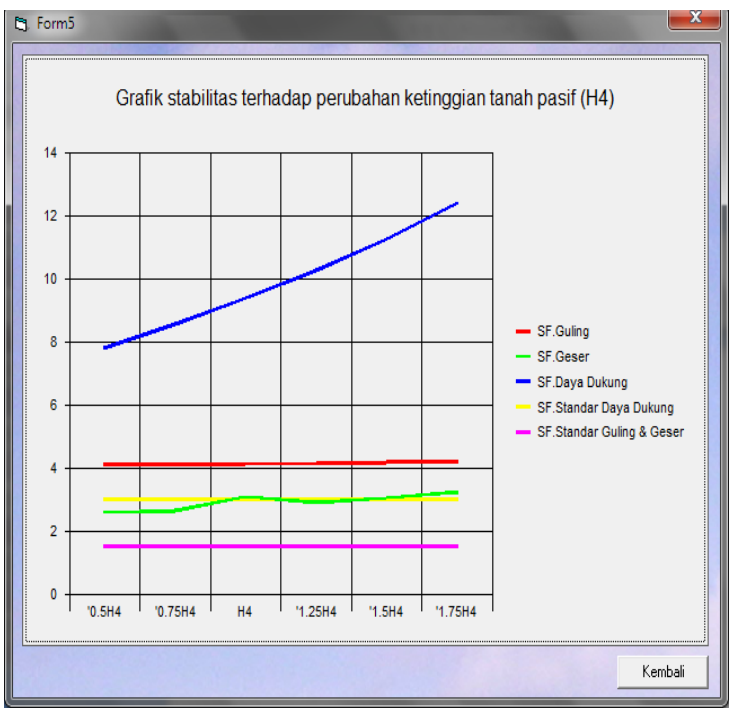

Gambar 3.17. Grafik Perubahan Nilai Stabilitas Dinding Berdasar Nilai $\mathrm{H}_{4}$ Pada Kondisi Dinamis

Gambar 3.16 dan Gambar 3.17 menunjukan hubungan antara dimensi $H_{4}$ dengan faktor keamanan terhadap guling, geser dan daya dukung pada kondisi statis dan dinamis. Grafik ini dapat digunakan sebagai acuan untuk melihat stabilitas dinding penahan tanah dengan cara merubah ketinggian dari $\mathrm{H}_{4}$ (memperkecil atau memperbesar tekanan tanah pasif) sehingga didapatkan dimensi dinding penahan tanah yang lebih efisien dan aman.

\subsection{Validasi}

Proses validasi dilakukan untuk mengetahui apakah perangkat lunak yang dibangun telah benar dan dapat di percaya hasilnya. Untuk mengetahui kebenaranya dilakukan dengan cara membandingkan hasil output yang didapat dari perangkat lunak dengan output yang didapat dari perhitungan manual. Berikut adalah hasil output yang didapat dari perhitungan dengan menggunakan program dan perhitungan manual.

Tabel 3.1. Rekapitulasi Validasi Program

\begin{tabular}{|c|c|c|c|c|}
\hline \multirow{2}{*}{ Stabilitas } & \multicolumn{2}{|c|}{ Program Retaining Wall } & \multicolumn{2}{c|}{ Perhitungan Manual } \\
\cline { 2 - 5 } & Statis & Dinamis & Statis & Dinamis \\
\hline Guling & 6.24 & 4,11 & 6,11 & 4,04 \\
\hline Geser & 3.68 & 3,09 & 3,64 & 3,05 \\
\hline Daya Dukung & 11.62 & 9.39 & 11.52 & 9,34 \\
\hline
\end{tabular}

Dari Tabel 3.1 terlihat bahwa hasil perhitungan yang diperoleh dengan menggunakan program ini hasilnya tidak jauh beda dengan perhitungan secara manual. Sehingga dapat dikatakan bahwa program perhitungan stabilitas dinding penahan tanah ini sudah benar dan dapat digunakan baik untuk kondisi statis maupun pada kondisi dinamis (gempa). 


\section{KESIMPULAN}

Berdasarkan hasil analisis dan perhitungan yang telah dilakukan, maka didapat kesimpulan :

1. Dari hasil analisis dengan menggunakan program dinding penahan tanah ini didapatkan dimensi dinding penahan tanah yang aman, relatif ekonomis sesuai dengan keperluan secara tepat dan mudah

2. Hasil perhitungan yang didapatkan dari program ini memiliki tingkat ketelitian yang lebih akurat dibandingkan dengan perhitungan secara coba-coba, dan juga waktu dan tenaga yang dibutuhkan juga lebih efisien.

3. Dengan adanya program ini, kita dapat lebih mudah dan cepat dalam mengecek kestabilan suatu dinding penahan tanah pada kondisi statis dan kondisi gempa.

4. Tampilan program yang sederhana, memudahkan kita dalam menggunakan program ini, baik dalam menginputkan data maupun dalam melihat hasil analisis dari program tersebut.

\section{UCAPAN TERIMA KASIH}

Ucapan terima kasih disampaikan pada Ditjen Dikti yang telah mendanai penelitian ini dalam skim Penelitian Mandiri tahun 2011 dan Lembaga Penelitian Universitas Andalas yang telah memfasilitasi kegiatan ini.

\section{DAFTAR KEPUSTAKAAN}

Dewobroto, Wiryanto , “Aplikasi Rekayasa Konstruksi dengan Visual Basic 6.0”, Elex Media.

Dwi Prasetyo, Didik, Tip an Trik Visual Basic 6.0, Elex Media.

M. Das, Braja (1983), Advanced Soil Mechanics, The University of Texas at El Paso, New York, USA, McGraw-Hill Book Company .

M. Das, Braja (1990), Principles of Foundation Engineering, second edition, Boston, PWS - KENT Publishing Company.

Supardi, Yuniar, Microsoft Visual Basic 6.0 untuk segala Tingkat, Elex Media.

Tim Peneliti dan Pengembangan Wahana Komputer (2002), Pembuatan Program Aplikasi (Retaining Wall) dengan Visual Basic 6.0, Jakarta, Salemba Infotek. 